\title{
A Landscape Similarity Index: Multitemporal Remote Sensing to Track Changes in Big Sagebrush Ecological Sites
}

\author{
Alexander J. Hernandez $z^{1}$ and R. Douglas Ramsey ${ }^{2}$ \\ Authors are ${ }^{1}$ Postdoctoral Fellow, RS/GIS Laboratories, Department of Wildland Resources, and ${ }^{2}$ Professor, Department of Wildland Resources, \\ Utah State University, Logan, UT 84322, USA.
}

\begin{abstract}
A similarity index for big sagebrush ecological sites was developed in northern Utah. In contrast to field measurements used to calculate similarity to reference states, our approach relies on the utilization of historic archives of satellite imagery to measure the ecological distance to benchmarks of undesired conditions such as invasion by exotic annuals and woodland encroachment. Our benchmarks consisted of locations for which there are field data collected for monitoring and evaluation purposes for several time periods. We utilized a temporal series of Landsat thematic mapper (TM) imagery that spanned 1984 to 2008 from which the soil-adjusted vegetation index (SAVI) and other transformations were extracted. Topographic and climatic variables were also included as ancillary data. Multidimensional scaling (MDS) was used to obtain scores in reduced ordination space for two periods of interest: 1984-1996 and 1997-2008. Interannual SAVI mean-variance plots provided evidence that the benchmarks and ecological sites have a distinct temporal response that allows an objective comparison. Our MDS results also show that natural clusters can be identified in the reduced statistical space for ecological sites that are a dominant component of a soil map unit. The two MDS solutions allowed the ordination of ecological sites in two gradients of productivity and bare ground. Interpretations of the transitions and trajectories of mountain, Wyoming, and basin big sagebrush sites correlated well with the ecological expectation. We anticipate that range conservationists and others actively working in rangeland evaluation can use this application to develop and update ecological site descriptions and state-and-transition models from a remotely sensed perspective.
\end{abstract}

Key Words: ecological site descriptions, invasive plants, multidimensional scaling, remote sensing, similarity index

\section{INTRODUCTION}

An ecological site description (ESD; USDA-NRCS 2008) and its associated state-and transition-model (STM; Westoby et al. 1989) provide information about the biophysical properties of a site along with descriptions of the different plant communities that can be found on that landscape. Information about the structure, composition, and dynamics of said plant communities given different disturbances or management scenarios can also be found in the ESD and its corresponding STM (Briske et al. 2005). Generally, rangelands can be evaluated using three different methods: trend, indicators of rangeland health, and a similarity index (USDA-NRCS 2008). Trend is used to determine the direction of change that occurs on a given site. Indicators of rangeland health are qualitative assessments that provide land managers and rangeland specialists with information to evaluate ecological processes, which can be used to identify potential areas of degradation (Pyke et al. 2002). Similarity indices are used to compare the existing conditions with a historic or desired state as defined by the ecological site description. The interpretation of trend, rangeland health, or similarity index can provide an indication of disturbances, as well as inform future management (USDA-NRCS 2006a).

At the time of research, Hernandez was a research and teaching assistant, Department of Wildland Resources, Utah State University, Logan, UT 84322, USA.

${ }^{*}$ Correspondence: Alexander J. Hernandez, RS/GIS Laboratories, Dept of Wildland Resources, Utah State University, Logan, UT 84322-5275, USA. Email: alex.j. hernandez@aggiemail.usu.edu

Manuscript received 19 October 2011; manuscript accepted 31 August 2012

(c) 2013 The Society for Range Management
These three methods often require comprehensive field surveys to collect the necessary ground data to conduct an ecological site assessment. For instance, in the similarity index, the current method is to collect, classify, and weigh annual production by species. This is done because the similarity index currently in use measures how comparable the percentage by weight of the plant community present on the site is to a desired or undesired state. Due to the high requirement for field data, it is clear that these methods are designed to evaluate specific areas of interest, and that their applicability to assess large landscapes, such as those found in rangelands of the western United States, might be limited due to the costs associated with field surveys.

For any ESD, a suite of ecological states can exist in its STM. Ecological states are normally distinguished by large differences in plant functional groups, soil properties, ecosystem processes, and consequently in vegetation structure, biodiversity, and management requirements. Ecological states are also distinguished by their reaction to disturbance (Pellant et al. 2005). For rangeland management, it is often necessary to be able to identify where on the landscape particularly undesirable states are present. For instance, for big sagebrush-dominated ecological sites, it is important to know where those states characterized by invasion of exotic annual grasses or encroachment by woodlands are occurring. It is also important to know which big sagebrush ecological sites are in the process of transitioning to an undesirable state. This type of problem calls for the application of the trend and similarity index methods to elucidate the direction of change, and how similar or dissimilar each site of interest is to undesired states. 
Due to the inherent cost of the application of the methods to evaluate rangelands, it is unlikely that large regions containing multiple ecological sites can be assessed in a timely manner. It is here then that historic remote sensing data sets can be used to derive quantitative indicators to determine condition in space and time so that trend and similarity of large landscapes can be obtained. An example is the protocol for the ecological monitoring of rangelands using multitemporal series of soiladjusted vegetation index (SAVI) that was prepared for areas of northern Utah (Washington-Allen et al. 2006). This application demonstrated how historic remote sensing imagery could provide reliable accounts of change in large areas.

In order to detect landscape change, it is necessary to define comparative benchmarks. Benchmarks are standards with which measurements of indicators can be compared (West 1991). Indicators can be composites of a group of measurements that are ideally independent of or uncorrelated to each other. If benchmarks can be objectively identified on the landscape and their remotely sensed spectral and temporal signatures are also characterized, then assessments of change can be done for relatively large regions. This is the primary assumption of the research presented in this paper.

To the best of our knowledge, an application that relates historic remote sensing data sets with ecological site descriptions for monitoring and assessment purposes has not been developed. Our objectives can be stated as follows: a) develop a remote sensing based similarity index for rangelands in the Intermountain West, and b) assess changes in condition for big sagebrush-dominated ecological sites for which preliminary STMs have been prepared.

Even though our similarity index does not have the resolution (spatial and/or thematic) to discriminate individual species, we believe that range conservationists will benefit from our landscape-level assessments that identify areas that are likely to be in or are approaching an undesired stable state. Work presented in this paper is expected to promote discussion and further methodological refinement on the utilization of remotely sensed datasets for the assessment of rangelands using ecological site descriptions.

\section{METHODS}

\section{Study Area}

Our research was conducted in the northwestern corner of the state of Utah, (lat 41 $6^{\prime} 27.36^{\prime \prime}-41^{\circ} 59^{\prime} 59.64^{\prime \prime} \mathrm{N}$, long $\left.114^{\circ} 2^{\prime} 31.2^{\prime \prime}-112^{\circ} 43^{\prime} 40.8^{\prime \prime} \mathrm{W}\right)$ in Box Elder County. We focused our work in the spatial domain of big sagebrushdominated ecological sites that are contained in the major land resource area (MLRA) D28A (USDA-NRCS 2006b), and that have a preliminary or final ESD and STM. Table 1 contains a list of the ecological sites that were considered in this study, along with a brief description of their main characteristics. Figure 1 depicts the spatial distribution of the ecological sites of interest in the context of the study area. The vegetation in the study area is primarily composed of salt desert scrub and big sagebrush steppe and shrublands, as well as pinyon-juniper ecosystems (SWReGAP 2004). The elevation ranges from 1278 $\mathrm{m}$ in the lowlands close to the Great Salt Lake to $3027 \mathrm{~m}$ in the Raft River range. The mean elevation is $1520 \mathrm{~m}$. The climate is generally dry, receiving an average of 267 millimeters of precipitation annually, typically in the form of winter snows and spring rains. Temperatures are usually cold in the winter (daily average of $-3^{\circ} \mathrm{C}$ ) and moderately hot in the summer (daily average of $20^{\circ} \mathrm{C}$ ). The yearly average temperature is $8^{\circ} \mathrm{C}$ (PRISM Climate Group 2004). The soils range from saline nonproductive in the lower elevations to fertile with a high content of organic matter in the mountains (Loerch et al. 1997). The ownership of the land can be divided into three categories: a) federal lands that are managed by the Bureau of Land Management (BLM; approximately 41\%) and the United States Forest Service (USFS; about 3\%), b) private ownership (about $43 \%$ ) and c) the state of Utah (approximately 13\%). The study area has undergone various disturbances ranging from grazing, burning, drought, and flooding events (Sant 2005).

\section{Ecological Site Units}

An ecological site and its description of climate, soils, and vegetation (USDA-NRCS 2010a) are related spatially to soil map units (SMUs) delineated by the Natural Resources Conservation Service in the Soil Survey Geographic (SSURGO) database (USDA-NRCS 2010b). Ecological sites are linked to components of one or more SMU. Components of map units attempt to capture the variability found within SMUs for soil patches that are below the minimum mapping unit of the SSURGO database. A SMU can have up to four components; therefore, these polygons can have a one-to-many correspondence with ecological sites (USDA-ARS 2010). Even though this brings about a cumbersome utilization of SMUs to spatially represent ecological sites, the process is possible. The SSURGO database contains an estimate of the percentage of every component that occupies a given SMU. Because the SMUs represents our basic sample unit, and given the potential internal variability of SMUs, we have chosen to develop our models with SMUs that contain a dominant ESD (>60\%). The selection of this cutoff was based on the assumption that this proportion would adequately represent the dynamics of the ESD. We consider that soil polygons complying with this criterion and being used to train models are sufficiently uniform. In this paper, soil map units (SMUs) and ecological site units are used interchangeably.

\section{Benchmarks}

Our rationale is that an assessment of an ecological site's condition (good, excellent, etc.), and trend (positive, negative, not apparent) can be attempted by comparing the temporally integrated remotely sensed signature of each ecological site unit to the signature of defined benchmarks. We define benchmarks as sites that have been properly identified on the ground and for which there has been credible ecological monitoring. This standard will allow us to assign a particular ecological state to an individual benchmark. Because we were interested in measuring similarity to undesired stable states (i.e., invasion by exotics, encroachment by woodlands), we put more emphasis in obtaining field data sets from which this type of information could be extracted. Field data used to define benchmarks were obtained from the Utah Division of Wildlife Resources, namely the Range Trend Studies (DWR-RTS) 
Table 1. Big sagebrush ecological sites included in this study. ${ }^{1}$

\begin{tabular}{|c|c|c|c|c|}
\hline Code & Name & Soil characteristics & Physiographic features & Climatic features \\
\hline R028AY215 & $\begin{array}{l}\text { Semidesert gravelly loam (Wyoming big } \\
\text { sagebrush) North }\end{array}$ & Loam, $152 \mathrm{~cm}$ deep; well drained & $\begin{array}{l}\text { Elev.: } 1300-1800 \mathrm{~m} \text { above sea level } \\
\text { Slope: } 2-15 \%\end{array}$ & $\begin{array}{l}\text { MAP: } 203-305 \mathrm{~mm} \\
\text { MAAT: } 7-10^{\circ} \mathrm{C} \\
\text { FFP: } 100-150 \mathrm{~d}\end{array}$ \\
\hline R028AY221 & Semidesert loam (basin big sagebrush) & Clay loam, $152 \mathrm{~cm}$ deep; well drained & $\begin{array}{l}\text { Elev.: } 1340-1800 \mathrm{~m} \text { above sea level } \\
\text { Slope: } 1-3 \%\end{array}$ & $\begin{array}{l}\text { MAP: } 203-305 \mathrm{~mm} \\
\text { MAAT: } 7-10^{\circ} \mathrm{C} \\
\text { FFP: } 100-150 \mathrm{~d}\end{array}$ \\
\hline R028AY226 & $\begin{array}{l}\text { Semidesert sandy loam (Wyoming big } \\
\text { sagebrush) }\end{array}$ & $\begin{array}{l}\text { Loamy sand, > } 152 \mathrm{~cm} \text { deep; well } \\
\text { drained }\end{array}$ & $\begin{array}{l}\text { Elev.: } 1370-1740 \mathrm{~m} \text { above sea level } \\
\text { Slope: } 1-10 \%\end{array}$ & $\begin{array}{l}\text { MAP: } 203-305 \mathrm{~mm} \\
\text { MAAT: } 7-10^{\circ} \mathrm{C} \\
\text { FFP: } 100-150 \mathrm{~d}\end{array}$ \\
\hline R028AY306 & $\begin{array}{l}\text { Upland gravelly loam (mountain big } \\
\text { sagebrush) }\end{array}$ & $\begin{array}{l}\text { Moderately coarse to medium, } 152 \\
\text { cm deep; well to somewhat } \\
\text { excessively drained }\end{array}$ & $\begin{array}{l}\text { Elev:: } 1300-2280 \mathrm{~m} \text { above sea level } \\
\text { Slope: } 3-20 \%\end{array}$ & $\begin{array}{l}\text { MAP: } 305-407 \mathrm{~mm} \\
\text { MAAT: } 7-11^{\circ} \mathrm{C} \\
\text { FFP: } 80-160 \mathrm{~d}\end{array}$ \\
\hline R028AY310 & Upland loam (mountain big sagebrush) & No preliminary ESD on record & & \\
\hline
\end{tabular}

${ }^{1}$ MAP indicates mean annual precipitation; MAAT, mean annual air temperature; FFP, freeze-free period; ESD, ecological site description.

(UDWR 2010). The DWR-RTS sites are surveyed every 5 yr to detect changes in vegetation composition for big game habitats. Established protocols are used to characterize vegetation (e.g., species composition, percent cover, density), and its trend (temporal changes in browsing quantity and quality, exotic grasses performance, expansion of woodlands).

For our purposes, data collected during 1996, 2001, and 2006 were used to assess the presence of undesired stable states (e.g., cheatgrass invasion or woodland encroachment) in DWR-RTS plots located within our study area. We selected these sites based on an analysis of the narratives and data tables publicly available on the DWR website. These reports offer a comprehensive description of species present on each site and their trends. For instance, if a site was described as having an invasion by exotic annual grasses (e.g., Bromus tectorum) and the narrative described a positive trend (e.g., increases in percent cover through time) then that site was selected to be a benchmark for this specific undesired state. The location of benchmarks throughout the study area can be found in Figure 1.

\section{Remote Sensing and Ancillary Datasets}

We utilized multitemporal remote sensing datasets as well as climatic and topographic information to find and describe an integrated spatial response of specific undesired stable states
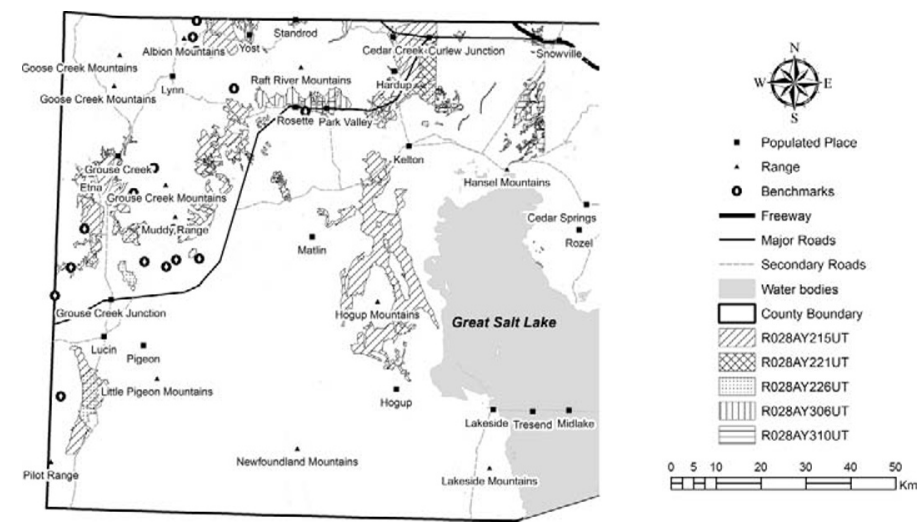

Figure 1. Distribution and type of big sagebrush ecological sites and Utah Division of Wildlife Resources (DWR) benchmarks in the study area. occurring in each benchmark location. We utilized a time series of Landsat thematic mapper (TM) imagery (Path 39/Row31) from 1984 to 2008. For every year, we obtained one scene collected during the growing season. An effort to obtain only imagery with the best quality was made throughout the collection process. Imagery was first rectified and resampled to a common map projection universal transverse mercator (UTM) Zone 12 WGS 1984, and then standardized by converting the raw digital numbers to exoatmospheric reflectance values using an image-based atmospheric correction procedure (Chavez 1996) with updated calibration coefficients for the Landsat TM sensor (Chander et al. 2009). For every year, we derived the SAVI and the brightness greenness wetness (BGW) components (Crist and Kauth 1986). SAVI has been found to work better than other indices such as the Normalized Difference Vegetation Index (NDVI) in semiarid environments due to the minimization of soil background effects (Huete 1988; Jensen 2007) and BGW has been successfully utilized in the Intermountain West for classification purposes (Lowry et al. 2007). Vegetation indices such as SAVI have been used to follow seasonal and interannual change in vegetation growth and activity (Jensen 2007); thus, it made sense to explore its performance in discriminating features of different stable states in big sagebrush systems. Table 2 contains a list of the dates, sun elevation angles, and percent cloud cover for the scenes that were used in this study.

In addition to the Landsat TM indices and transformations, we also utilized information generated by the Earth Resources Observation and Science (EROS) data center. EROS has developed a comprehensive suite of remote sensing phenology datasets (USGS-EROS 2010) for the past $20 \mathrm{yr}$ (1989-2008). This data set includes variables such as a) beginning and end of measurable photosynthesis in the vegetation canopy; b) length of photosynthetic activity - the growing season; and c) canopy photosynthetic activity across the growing season, among others. In total there are nine variables that describe the annual phenological regime throughout the continental United States for the period of record. This type of information was included to enhance our understanding of the spatiotemporal dynamics of vegetation in our study area. For example, those sites that have been invaded by cheatgrass will experience early onsets in 
Table 2. Landsat thematic mapper (TM) Path 39/Row 31scenes utilized in the study.

\begin{tabular}{llcc}
\hline Year & Acquisition date & Sun elevation angle $\left(^{\circ}\right)$ & Cloud cover $\%$ \\
\hline 1984 & 18 July & 58.05 & 0 \\
1985 & 5 July & 59.81 & 0 \\
1986 & 9 August & 53.18 & 0 \\
1987 & 12 August & 53.34 & 0 \\
1988 & 14 August & 53.36 & 0 \\
1989 & 17 August & 52.12 & 0 \\
1990 & 3 July & 58.38 & 10 \\
1991 & 20 June & 59.60 & 0 \\
1992 & 24 July & 56.13 & 0 \\
1993 & 25 June & 59.34 & 0 \\
1994 & 14 July & 56.85 & 0 \\
1995 & 17 July & 54.22 & 0 \\
1996 & 9 July & 55.67 & 0 \\
1997 & 4 June & 60.57 & 10 \\
1998 & 9 July & 60.74 & 0 \\
1999 & 12 July & 60.32 & 0 \\
$2000^{1}$ & 22 July & 60.80 & 0 \\
$2001^{1}$ & 25 July & 60.01 & 0 \\
$2002^{1}$ & 28 July & 59.39 & 0 \\
$2003^{1}$ & 28 May & 62.83 & 0 \\
2004 & 10 August & 55.97 & 0 \\
2005 & 13 August & 55.95 & 0 \\
2006 & 13 June & 64.40 & 03.82 \\
2007 & 2 July & 63.45 & 0 \\
2008 & 18 June & & 0 \\
\hline & & 5 & 0 \\
5 & & & 0 \\
\hline
\end{tabular}

${ }^{1}$ Scenes from Landsat enhanced thematic mapper plus (ETM+).

photosynthetic activity that can be detected in the multidimensional signal of these phenology products.

A digital elevation model (DEM) and derivatives such as slope, aspect, compound topographic index (CTI), and a modification to the original topographic relative moisture index (TRMI) (Parker 1982) were also included in this analysis. Climatic variables such as annual average precipitation and maximum and minimum temperatures were also prepared using a continental data set (PRISM Climate Group 2004).

\section{Preparation of the Modeling Dataset}

SMUs dominated $(>60 \%)$ by a specific ESD and the defined benchmarks were integrated into a data set that could be used to assess similarity to undesired stable states. Our benchmarks were made up of specific geographic point locations while polygons (SMUs) defined our ecological site units. To put everything into the same context, we created 1-ha buffer areas around the coordinates of each benchmark. We attempted to simulate an area equal to three Landsat TM pixels $(90 \times 90 \mathrm{~m})$ in square $\left(8100 \mathrm{~m}^{2}\right)$. Once we had a combined shapefile of SMU and benchmark polygons, we utilized a zonal statistics procedure to extract the local mean and variance for each polygon from our remote sensing, topographic, and climatic data sets. We expected that a temporal series of mean and variance of a vegetation index, transformations (i.e., BGW), or phenology variables would provide insight about the spatiotemporal dynamics of vegetation composition in our bench- marks and SMUs. Thus, our modeling data set consisted of a matrix in which the rows consisted of each benchmark and soil mapping unit correlated to a given ecological site, and the columns corresponded to means and variances extracted from each spectral, topographic, or climate variable.

\section{Approach to Integration and Similarity}

We needed to estimate a unique or integrated value for benchmarks and for ecological site units from their multivariate (vegetation indices, topographic, climatic) response. We approached these problems of integration and similarity from an ordination perspective. Ordination provides a geometric representation of individuals (benchmarks and SMUs in our case) in a low-dimensional space, so that the distances between the individuals represent their dissimilarity. In addition, this method has been shown to provide insight into whether natural clusters exist or can be generated from a multivariate dataset (Kelly and Basford 2000). Ordination has also been used to reveal underlying trends in the composition of vegetation communities through the analysis of changes in vector position in reduced space over time (Foran et al. 1986).

There are many techniques that attempt to condense information from a multivariate data set into a reduced dimensional space. Ordination techniques such as principal component analysis (PCA), and canonical correspondence analysis (CCA), among others, are available for ordination purposes. In our case, we decided to utilize multidimensional scaling (MDS). As with any other ordination technique, MDS concentrates the original information contained in many variables into a suite of ordered scores for a few new attributes that define the dimensions of the new reduced space (Lattin et al. 2003). We selected this technique because MDS has been known to rearrange objects in an efficient manner through the minimization of stress. In multidimensional scaling, stress measures the difference between the original dissimilarity of the individuals and the way in which this is represented as distances on the ordination space (StatSoft 2010). By controlling stress, MDS provides an excellent representation of the data in which most of the relevant information has been preserved with fewer variables (Kelly and Basford 2000).

Ordination With Multidimensional Dimensional Scaling (MDS) We conducted MDS on our data set for two periods of interest. The first period spanned 1984 to 1996, and the second 1997 to 2008. Our criterion to split the data set into these two periods is based on the fact that vegetation composition and trend information contained in the narratives from DWR-RTS are available for 1996, 2001, and 2006. In this way, 1996 seemed like a reasonable year to partition the data set, and then relate the MDS results to the narratives and tables found in the DWRRTS reports. The end of the second period (year 2008) is $2 \mathrm{yr}$ after the last DWR-RTS assessment of condition and trend. Prior to conducting MDS, we scaled all the variables due the inherent difference in units among remote sensing, topography, and climate variables. While preparing the data set for modeling, we found that several pixels in the EROS phenology variables had very unusual values that were likely errors or missing data. We needed to declare these records as missing data because we did not have a method to interpolate new values from the 
surrounding pixels. These types of records had to be removed from the data set because the algorithms that are used to run MDS cannot handle missing values in the distance matrix.

When running MDS, there are two issues that need to be addressed; one is which type of distance metric will be used to calculate the matrix of dissimilarities, and the other is to determine the number of dimensions in the reduced space. We observed that the type of distance that is used greatly influences the number of dimensions or axes generated. To determine the number of axes, we ran the Kruskal's Metric Multidimensional Scaling (Cox 2001) implementation in R (R-Project 2010). We generated different $k$-dimensional MDS solutions to measure improvements in fit as we increased the number of dimensions. Each $k$-dimensional configuration is designed to minimize the stress between the input distances and the distances in reduced space, and thus is our measure of fit (Lattin et al. 2003). From each MDS solution, we extracted the value of stress and prepared scree plots to graphically assess the improvements in fit or reductions in stress with an increasing number of axes. We tested this process with several distance methods (i.e., Euclidean, Maximum, Manhattan, Canberra). We decided to utilize the Manhattan method, which provided better values of stress with fewer dimensions when compared to the other distance methods. Once the optimum number of dimension was selected, we obtained MDS solutions by using the multidimensional scaling implementation in $\mathrm{R}$ for our two periods of analysis (1984-1996, 1997-2008) independently.

\section{Trajectories and Maps of Similarity}

One of our assumptions was that the ordered scores in the reduced MDS space could be considered as the integrated response for a given ecological state in a specific benchmark or SMU at a certain time. In this context, the distance of any SMU to one benchmark on the MDS axes can be used to assess the similarity in vegetation mean and variance between a SMU and the benchmarks. Because we generated two temporal MDS solutions (1984-96, 1997-2008), we were able to follow the changes in ordination space for a given SMU and/or benchmark, and interpret whether the trajectories were suggesting changes or stability through time from a remotely sensed perspective.

We also extracted the matrix of distances between SMU and benchmarks and then attached that information to the SMUbenchmarks geospatial database (shapefile) that we had used for sampling purposes. By having this piece of information in our geospatial database we were then able to compose maps of this ecological distance. In other words, we could map the similarity of each SMU to an undesired state (e.g., cheatgrass, woodland encroachment) found in a specific benchmark. This type of map can be used to readily identify which SMU are more similar or dissimilar to a certain undesired state.

\section{RESULTS}

\section{Multitemporal Signatures: Steady-States Plots}

An exploratory analysis of the modeling data helped us determine how well the benchmarks and ecological site units were partitioned in multitemporal space. Figure 2 shows the
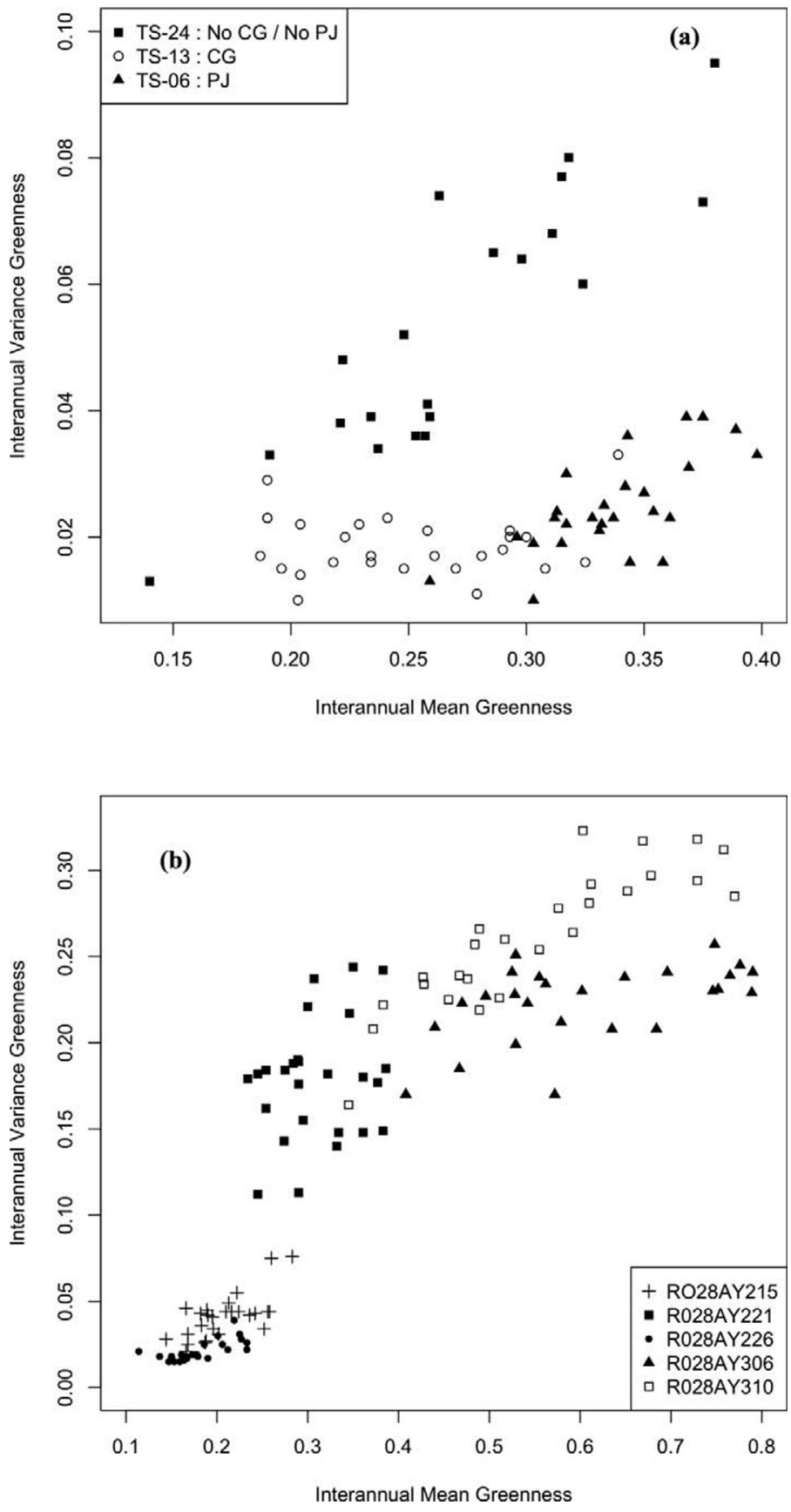

Figure 2. Steady states plots for a, benchmarks and b, ecological site units. Observe the segmentation in greenness space among the shown sites and benchmarks that clearly indicate that a multitemporal remote sensing signal can be used to separate ecological states.

natural clusters derived from plotting the mean and variance of the interannual (1984-2008) SAVI for a) some of our benchmarks, and b) representative polygons for a suite of ecological sites. In this plot, each point represents the mean/ variance of greenness captured for a specific year of the analysis. Only a few benchmarks and polygons are included for graphic simplicity. Although overlaps do exist among benchmarks and ecological sites, naturally occurring groups can still be discriminated by using these two parameters.

The distribution of points in spectral space correlates well with what would be anticipated for the selected benchmarks. 
Table 3. Synthesis of major disturbances extracted from Utah Division of Wildlife Resources-range trend series (DWR-RTS) narratives.

\begin{tabular}{|c|c|c|}
\hline Benchmark & Observed trend 1996 & Observed trend 2006 \\
\hline TS-02 & $\begin{array}{l}\text { Improvements in Wyoming big sagebrush cover since } 1990 . \\
\text { Cheatgrass is widely distributed across the site and abundant. }\end{array}$ & $\begin{array}{l}\text { Wyoming big sagebrush density declined } 22 \% \text {. Cheatgrass cover } \\
\text { was up to } 5 \% \text {, and is nearly half of the total grass cover. Site } \\
\text { could be susceptible to fire. }\end{array}$ \\
\hline TS-04 & $\begin{array}{l}\text { Mountain big sagebrush cover slightly down, grass cover up, forbs } \\
\text { stable, cheatgrass present. }\end{array}$ & $\begin{array}{l}\text { Cheatgrass cover down, Mountain big sagebrush cover declined, } \\
\text { grass and forb cover up. }\end{array}$ \\
\hline TS-05 & Cheatgrass abundance low, shrub cover stable, forb cover up. & Shrub, grass, and forb cover declined, cheatgrass cover up. \\
\hline TS-06 & Shrub and grass cover stable compared to 1990 , forb cover down. & $\begin{array}{l}\text { Basin big sagebrush and black sagebrush declined, increase in bare } \\
\text { ground and juniper cover, cheatgrass cover declined. }\end{array}$ \\
\hline TS-07 & $\begin{array}{l}\text { Black sagebrush cover stable, grass and forb cover up, traces of } \\
\text { cheatgrass cover. }\end{array}$ & $\begin{array}{l}\text { Shrub cover declined, grass and forb cover down, increase in } \\
\text { cheatgrass and bare ground cover. }\end{array}$ \\
\hline TS-11 & $\begin{array}{l}\text { Shrub and grass cover down from 1990, cheatgrass is a significant } \\
\text { component. }\end{array}$ & $\begin{array}{l}\text { Shrub cover declined, grass cover stable, cheatgrass is major } \\
\text { component but no significant change from } 2001 \text {. }\end{array}$ \\
\hline TS-12 & Basin big sagebrush stable, grass cover declined. & $\begin{array}{l}\text { Increase in bare ground, cheatgrass cover declined, shrub cover } \\
\text { stable. }\end{array}$ \\
\hline TS-13 & $\begin{array}{l}\text { Wyoming big sagebrush recovering, grass and forb cover up, } \\
\text { cheatgrass is a significant component. }\end{array}$ & $\begin{array}{l}\text { Big sagebrush cover declined, significant increases in cheatgrass } \\
\text { cover, grass and forb cover stable. }\end{array}$ \\
\hline TS-14 & $\begin{array}{l}\text { Shrub cover slightly improving, grasses stable and dominant } \\
\text { cheatgrass. }\end{array}$ & Mountain big sagebrush declined, grasses down, forb cover up. \\
\hline TS-15 & $\begin{array}{l}\text { Mountain big sagebrush improving from 1990, competition with } \\
\text { trees, grasses stable and forb cover up. }\end{array}$ & $\begin{array}{l}\text { Big sagebrush recovering after fire, grass and forb cover up, } \\
\text { cheatgrass found but only traces. }\end{array}$ \\
\hline TS-18 & $\begin{array}{l}\text { Wyoming big sagebrush declined, grass and forb cover down, } \\
\text { cheatgrass cover increasing. }\end{array}$ & $\begin{array}{l}\text { Big sagebrush declined, cheatgrass cover increasing, grass and forb } \\
\text { cover stable. }\end{array}$ \\
\hline TS-24 & $\begin{array}{l}\text { Mountain big sagebrush cover stable from 1990, grass and forb } \\
\text { cover up, cheatgrass declined. }\end{array}$ & $\begin{array}{l}\text { Big sagebrush cover increased, cheatgrass declined, grass and forb } \\
\text { cover up. }\end{array}$ \\
\hline
\end{tabular}

For instance, site trend series TS-13 (Fig. 2a; Table 3) where cheatgrass is the dominant vegetation, occupies the bottom center of the plot. A monoculture of cheatgrass should show moderate productivity (depending on the time of the year) and the uniform canopy is expressed by the small variance in greenness. Monocultures such as cheatgrass should have a narrow range of variability but a wider range of mean greenness, primarily influenced by interannual precipitation patterns.

We observe a quite different response for benchmark TS-24, composed primarily of sagebrush. The wide range in the greenness variance indicates a higher diversity (i.e., grasses, forbs, and shrubs) compared to the cheatgrass monoculture. Figure $2 \mathrm{~b}$ provides the same information but for different soil mapping units that are primarily composed of one ecological site. This indicates that the spatiotemporal data set offers enough information to separate the mean response in vegetation composition between ecological sites. With this piece of graphical evidence, we felt that enough information was contained in our data set to proceed with the ordination analysis.

\section{MDS Solutions and Separation of Ecological Sites}

For both MDS efforts (1984-1996, 1997-2008), we determined that two dimensions could adequately represent the transformed observations. From the scree plots (not shown here) it was obvious that the stress abruptly dropped from one to two dimensions for both periods of analysis. Using more than two dimensions evidently provided a better fit, but the gains in stress minimization did not seem to compensate for the increased complexity. Adding a third dimension did reduce the stress by approximately 2.5 units, but at the same time made the interpretation of the final solution more difficult.

Figure 3 shows the 1984-1996 MDS solution for the big sagebrush SMUs occurring in the study area: R028AY215, R028AY221, R028AY226, and R028AY306. In this and other MDS plots, each point represents a unique SMU or ecological site unit that has been previously correlated to a particular ecological site. The upper plot (Fig. 3a) shows the MDS scores for all the SMUs, regardless of the size of the soil component. We see that even though some clusters can be discriminated in the figure, there exists a significant amount of overlap among ecological sites. Many SMUs shown in the figure do not have a major soil component and therefore cannot be correlated to just one ecological site. If a SMU has multiple components, then by definition these components represent different ecological sites on the ground. This might explain the observed overlap and lack of distinct clusters. Another explanation for the amount of overlap might be the differences in community phase within a given ecological site. We see a different situation in Figure $3 \mathrm{~b}$ in which a threshold was set for the soil component. In this case, we only show those SMUs that have a major soil component, and therefore ESD, occupying at least $60 \%$ of its area. In this case most ecological sites occupy distinct areas in the reduced MDS space. This suggests that the best representations can be obtained from those SMUs that have a dominant ecological site component. The exception is the ESD R028AY226. The SMUs for this ESD occupy three different sections of the plot. None of these SMUs had a dominant component. They were included in the analysis only for comparison purposes. This situation emphasizes the need to apply our analysis techniques only to 
Big Sagebrush Sites - MDS 1984-1996

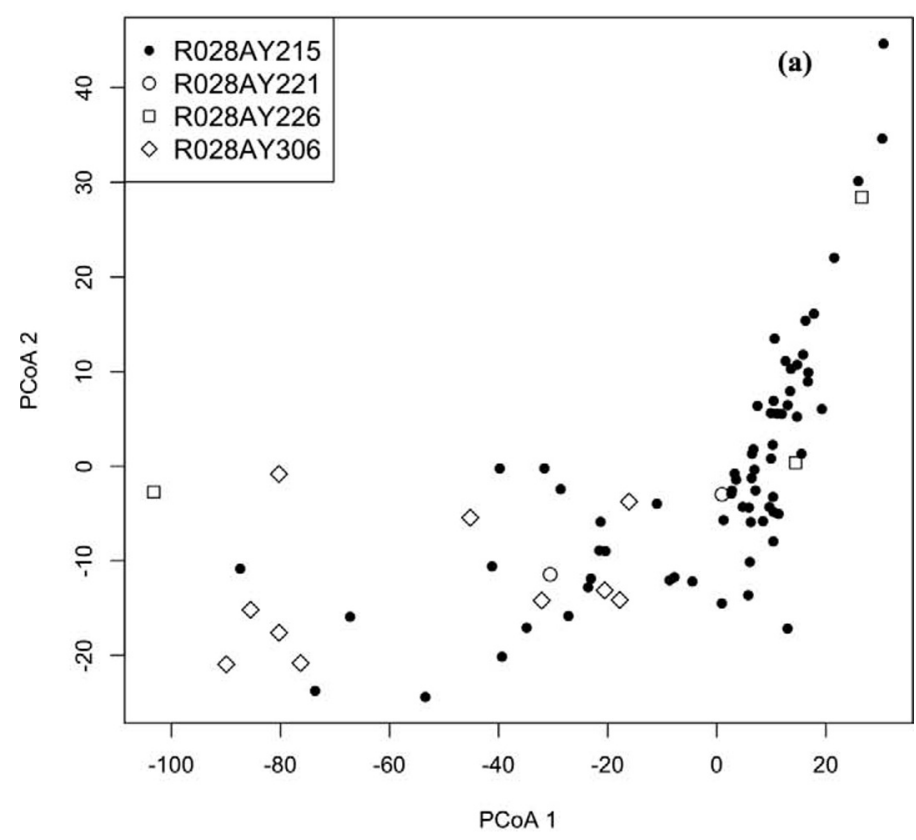

Big Sagebrush Sites - MDS 1984-1996

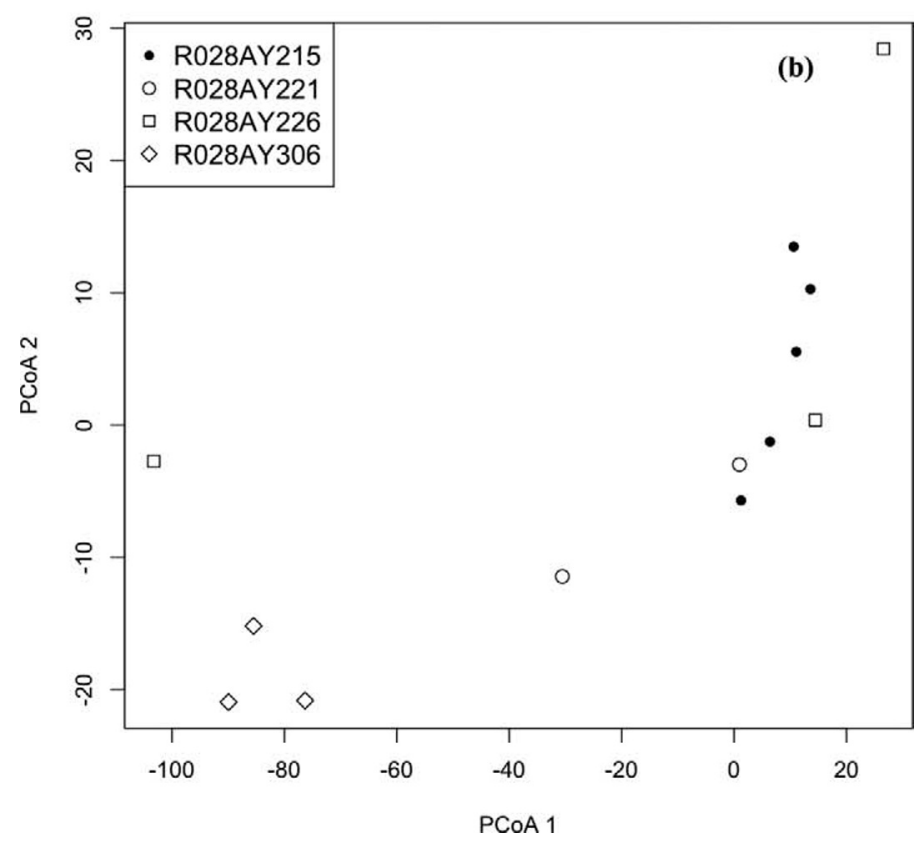

Figure 3. Multidimensional scaling (MDS) solution for the period 19841996: a, includes all the soil map units (SMUs), b, units with a major soil component $(>60 \%)$. Notice that the MDS solution has been able to separate among ecological sites, a better distinction is obtained when only using the SMUs that have a predominant soil component, however.

map units that are dominated by one ESD. We presume that if soil map units were generated at a fine enough scale to encompass only one ecological site, the similarity index could be applied to all SMUs.

\section{Vector Migration and Interpretation of MDS Dimensions}

Because our data sets have been scaled and then ordered, the time trajectories of each ecological site traced through

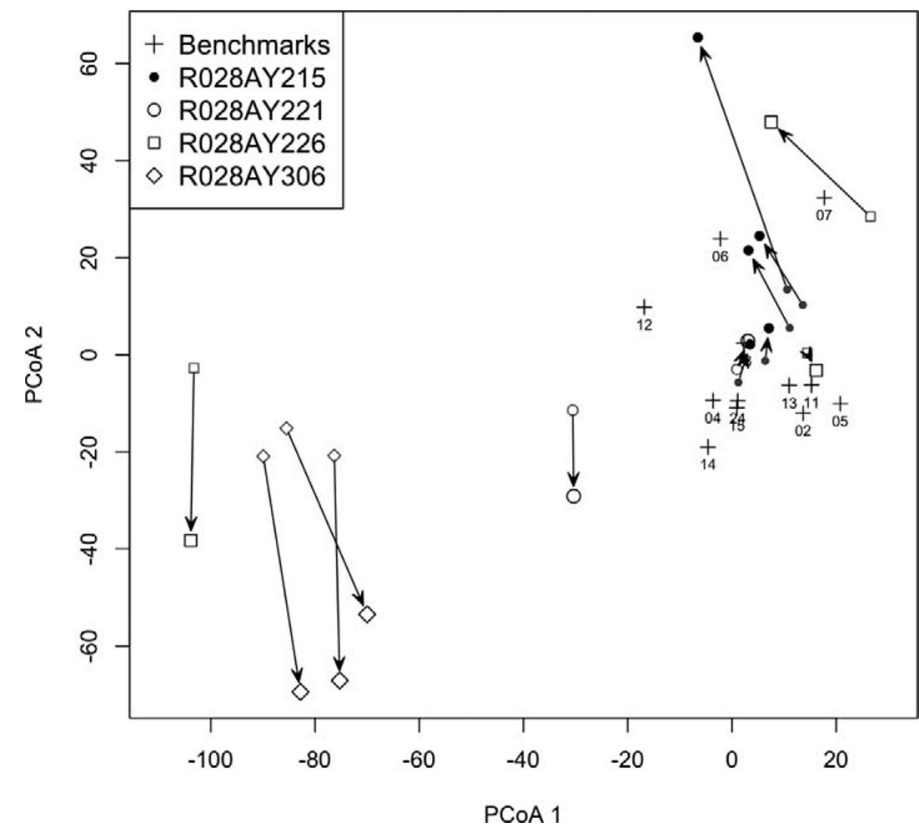

Figure 4. Vector migration: big sagebrush sites-multidimensional scaling (MDS) solutions for the 1984-1996 and 1997-2008 periods. Arrows indicate the direction of change in vector position from 1996-2008. The direction of change can be associated with a given benchmark condition (cheatgrass invasion, pinyon-juniper encroachment in 2008), and its location in reduced space to assess the proximity of a soil map unit (SMU) to an undesired state.

ordination space allows evaluation of spatiotemporal changes. The vector movement in the reduced space from 1996 to 2008 for the different ecological site units is presented in Figure 4. All landscape features are subject to change, but some site's current scores tend to separate more from the scores obtained for 1984-1996. For instance, all the SMUs correlated to the ecological site R028AY306 seem to have experienced more changes (represented by larger vector migrations) from 1996 to 2008. On the other hand, the majority of SMUs for the ecological site R028AY215 do not show large vector movements. It is interesting though that the SMUs for the selected ecological sites still form distinct clusters in the ordination space for the new period 1997-2008. This may suggest that when faced with a disturbance, the SMUs for this ecological site tend to respond similarly. In Figure 4 we also included the 97-08 MDS scores for our benchmarks. Sites TS-02, TS-05, and TS-13 are associated with cheatgrass invasion, whereas TS-06 has been documented with increases in pinyon-juniper cover. It is evident that SMUs belonging to R028AY215 are more closely related to the benchmarks. These types of plots not only provide information about the magnitude of the SMUs' vector migrations and thus change in time, but also can be used as a guideline to assess how similar to undesired conditions some of the SMUs have become.

This assessment of the magnitude of change should be accompanied by an interpretation of what the movements in vectors might imply. With so many variables involved in the ordination analysis, it is somewhat difficult to provide a comprehensive interpretation of the MDS dimension's meanings. We decided to utilize the trend narratives found in the 


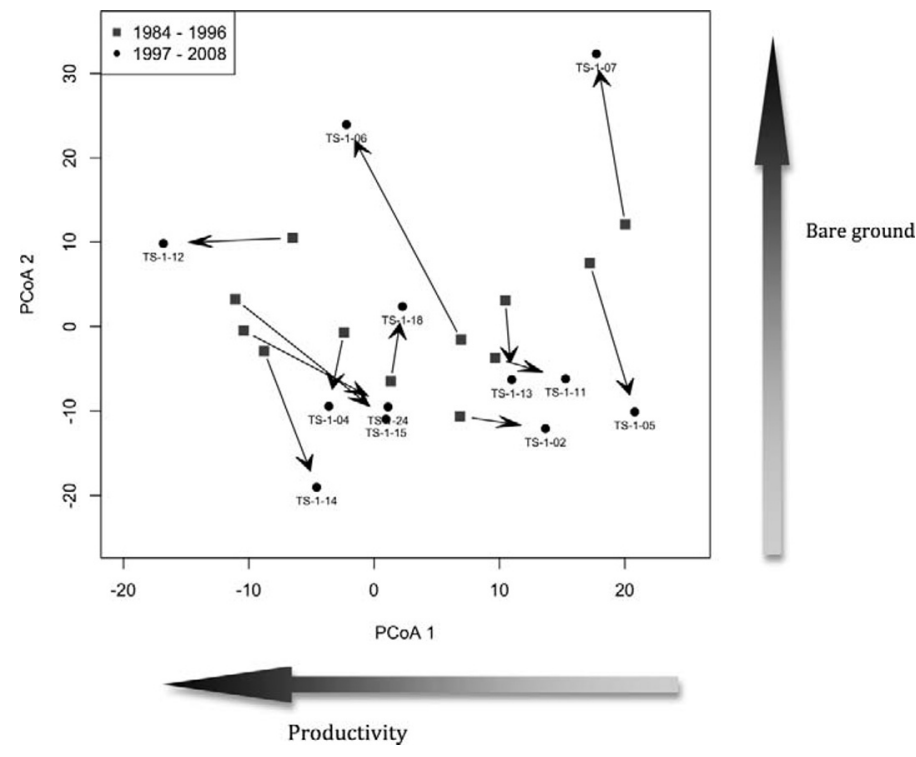

Figure 5. Multidimensional scaling (MDS) solution for the 1984-1996 and 1997-2008 periods for the benchmarks. Arrows inside the plot indicate the direction of change whereas the arrows outside denote gradients of plant productivity and bare ground as interpreted from the dynamics observed in 1996 and in 2006 in the Utah Division of Wildlife Resources benchmarks (see Table 3).

DWR-RTS for the field benchmarks as a plausible source to provide some power of explanation for the ordination space. Figure 5 shows all of the range trend studies benchmarks utilized in this study with the ordination scores for both periods of analysis, and arrows representing the direction of change. A synthesis of the major observations extracted from the DWRRTS narratives is provided in Table 3. Based on our interpretation of the identified trends in the narratives, it seems that the first MDS dimension is a measure of productivity, and its spatial and temporal variability increases from right to left; the second dimension seems to be related to the amount of bare ground that increases with the vertical axis. We have identified that those benchmarks located in the lower-right region of the ordination space have generally migrated to monocultures of cheatgrass. Those benchmarks that have shifted towards higher values in the second dimension have generally experienced increases in the proportion of bare ground cover, according to the DWR-RTS narratives.

Once MDS dimensions have acquired some interpretability, the migrations observed in the reduced space should provide the reader with information to assess which ecological sites are showing certain tendencies. Among those tendencies, we can mention dynamics such as becoming less productive, increasing bare ground, or moving towards a monoculture. Finally, Figure 6 shows a sample of our similarity maps. In this figure each SMU is represented on a gradient of similarity to a particular benchmark of either cheatgrass or woodland encroachment. We conducted comparisons between the level of similarity shown on these maps and our photographic record of some sites visited on the ground, and we observed an acceptable level of correspondence. For instance, some SMU with a high degree of similarity (according to the map) to a cheatgrass stable state had an ample cover of the noxious grass on the ground.
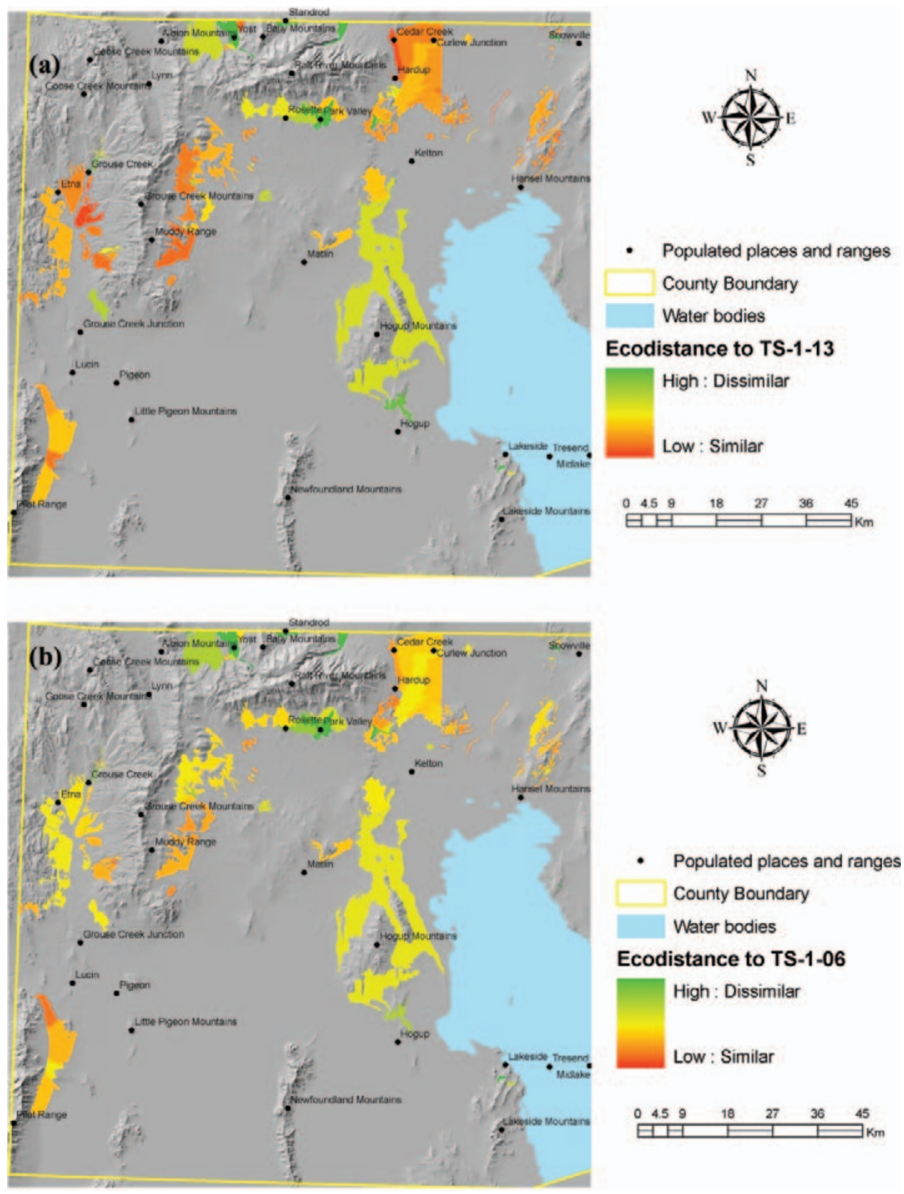

Figure 6. Samples of similarity maps; a, distance to a cheatgrass state, and $\mathbf{b}$, distance to a woodland encroachment state. Each soil map unit (SMU) is colored in a gradient from very similar to highly dissimilar with regards to the conditions found in benchmark TS-13 (identified as cheatgrass-dominated state) and in benchmark TS-06 (known to have pinyon-juniper encroachment conditions).

\section{DISCUSSION}

The standard concept of a similarity index as defined by the USDA-NRCS (USDA-NRCS 2006a) requires the collection of field data that are of high thematic (i.e., identification of plant species), and spatial (i.e., a small field plot) resolution. In addition, the emphasis is in the measurement of similarity to reference states described in the state-and-transition model of the ecological site. Our approach to similarity uses coarser resolutions, given that we worked with geospatial data sets with a pixel size of $30 \mathrm{~m}$, and no effort was made to classify the landscape into life forms or land cover types. Moreover, we measured similarity to undesired conditions occurring on the landscape, such as invasion by exotic annual grasses. Our rationale was that undesired states can be readily identified on the field, and can be described using an integrated response from a multivariate dataset. From a management perspective, it makes sense to attempt to identify areas of interest that are on a path to conversion or have already converted to a negative condition so that resources can be allocated for prevention or restoration purposes respectively (Wisdom et al. 2005a,b). In spite of the differences and limitations of low thematic 
precision of our approach, it has been recognized (Bestelmeyer et al. 2003; Hunt et al. 2003; Washington-Allen et al. 2006) that remote sensing is a cost-efficient technology used to evaluate the spatiotemporal dynamics of large landscapes.

Our mean-variance plots (Pickup and Foran 1987) were able to separate the interannual response of vegetation in each selected benchmark and SMU (Fig. 2). Ecological sites are unique due to their response to climatic conditions and disturbance (Briske et al. 2005). This was reflected in our steady-states plots because ecological site units occupied distinct areas of the mean-variance greenness space. An example can be the comparison of the SMU correlated to the ecological site R028AY306 (mountain big sagebrush) that is expected to perform differently than SMUs from the ecological site R028AY215 (Wyoming big sagebrush) in terms of plant productivity and diversity. The mountain big sagebrush SMU occupied the upper right section of the mean-variance plot, which indicates higher heterogeneity and vegetation canopy cover (Washington-Allen et al. 2008). The Wyoming big sagebrush SMU occupied an area with lower greenness mean and variance, which indicates both lower plant productivity and diversity.

The use of historic archives of satellite imagery and their derivative vegetation indices provides explanatory power to assess ecological sites. This appears to be a recent application in the scientific arena. An effort to identify spectrally anomalous locations in ecological site units was conducted in the Montana plains (Maynard et al. 2007). Landsat enhanced thematic mapper (ETM) imagery for 3 yr (2000-2002) was classified based on departures from mean values in the tasseled cap transformation (Crist and Kauth 1986) and then compared to locations in the field that were inside the norms of productivity and exposed soil according to their ecological site description. Our results indicate that a longer time series spanning 20 or more yr seems to be necessary to adequately separate different ecological states based on the inherent year-to-year variance of these ecosystems. At least in our case, the long-term data set seemed to provide natural clusters associated to a specific ecological site. Furthermore, the distinct spatiotemporal signature that was obtained for the benchmarks of either cheatgrass or woodland encroachment reinforced our objective to develop a similarity index that works at the ecological site unit spatial level.

Ordination techniques to assess and monitor rangelands have been broadly reported in the literature. For example, clustering was used to identify ecological stages in grass prairies (Uresk 1990). Principal component analysis and then clustering was used to classify and monitor Wyoming big sagebrush shrub-steppe habitat (Benkobi et al. 2007), and a two-way indication species classification analysis was used to determine sagebrush-grass states based on species composition data from transects to elaborate state and transition models (Allen-Diaz and Bartolome 1998). Each of these applications was based on field data that only allowed inferences about discrete locations on the ground and for a particular snapshot in time. Our approach, on the other hand, is the first attempt to ordinate ecological sites based on long-term remotely sensed data sets that cover entire landscapes as well as several time periods.

We conducted ordination for two periods (1984-1996 and 1997-2008) to track changes in a reduced statistical space, and also to explain change with plausible supporting data. The transitions (changes in vector position) observed for the benchmarks (Fig. 5) had a reasonable direction and magnitude when contrasted against the DWR-RTS narratives. This analysis also provided sensible interpretations for the MDS axes. Our assertion after this examination and interpretation is that the transitions observed for ecological site units should also be credible because the same data sets were used for benchmarks as well as soil mapping units. Our results seem to be in agreement with the claim that "if data from a series of sites at different times are ordered, then the time trajectories of each site traced through ordination space will allow a successional direction to be indicated" (Austin 1977). In other words, changes in ordination space for a given sphere of observations should produce trajectories that suggest either change or stability.

The SMUs correlated to ecological site R028AY306 migrated to a lower vector position in the second MDS axis, but stayed relatively constant in the first dimension. Based on our interpretation of the MDS solution, this means that the proportion of bare ground in these units decreased, while keeping their productivity relatively stable from 1996 to 2008. Based on the description for R028AY306 (mountain big sagebrush), this ecological site should not be greatly vulnerable to adverse transitions given its soils, climate regime, and elevation gradient. Our ordination results appear to support this idea because the SMUs correlated to this ecological site are dissimilar to benchmarks of undesired states. Conversely, R028AY215 (Wyoming big sagebrush) is known to be less resistant to disturbances such as fire and overgrazing (Pellant 1996; Wisdom et al. 2005b). Our MDS scores (Figs. 3 and 4) also seem to correspond well with this description. The SMUs for R028AY215 tend to occupy areas with relatively low productivity, while at the same time have scores that are similar to some of the benchmarks (Fig. 5) for cheatgrass. Based on our interpretation of the MDS axes, the upward migrations correspond to increases in bare ground. The magnitude of the migration can be related to the amount of disturbance that those sites have experienced. For instance, a site that moved a long distance between periods of analysis could have faced big impacts, which have removed most of the vegetation cover. The SMUs for R028AY221 (basin big sagebrush), occupy an area between R028AY306 and R028AY215 in the MDS solution. These units are usually found in deep, well-drained soils, whereas Wyoming big sagebrush sites are typically located in shallower soils. In terms of productivity, this could explain the location that SMUs correlated to R028AY221 occupy in the ordination space. One of the SMUs for this ecological site migrated to a very similar position in the ordination plot occupied by R028AY215, whereas another drifted down the second axis in what could be interpreted as a reduction of the bare-ground portion of that particular SMU. We were not able to draw inferences about what might be happening in the SMUs correlated to R028AY226 because they did not exhibit a congruent cluster in the reduced space. Recall that this ecological site was included for illustration purposes only and we could not locate SMUs correlated to this site that had a dominant soil component. We can only conclude that the noncongruency of this ecological site is due to the diversity of ecological sites occurring within the available SMUs. 
An application to assess similarity to undesired states that works for rangeland landscapes has been developed. The procedure is based on the definition of benchmarks that are readily identifiable in the field and that represent undesired conditions against which ecological site units can be contrasted and evaluated. The repeatability of this approach depends on the utilization of high quality: long-term archives of remotely sensed data coupled with field based monitoring sites for which there have been multitemporal observations of plant community composition. The underlying premise of our similarity index is that spatiotemporal multivariate signatures clearly discriminate undesired conditions in big sagebrush ecosystems.

Ordination techniques, such as multidimensional scaling, seem to be appropriate to a) reduce the dimensionality of a large data set, b) estimate an integrated response for both benchmarks and ecological site units, c) provide sensible and interpretable axes that allow describing ecological site units in terms of productivity and proportion of bare ground, and d) track the trajectories of the units of interest in reduced space. This technique permits the evaluation of similarity to undesired conditions as well as to provide insight about current states and transition that ecological site units have experienced on the landscape.

The ordination results for the ecological sites evaluated in this work seemed to comply well with the ecological expectation. The site R028AY306 (mountain big sagebrush) migrated to regions in the reduced space that are thought to have a greater cover of vegetation, while keeping the productivity relatively constant. This might be explained by conditions in which there is a relatively high vegetation density but the vigor or quality of said vegetation is low or decadent. The SMUs correlated to the Wyoming big sagebrush ecological site R028AY215 tended to occupy a region of relatively low productivity and a wide range of bare ground conditions. SMUs for this ecological site had the closest proximity to the benchmarks for cheatgrass and woodland encroachment. No distinct transitions were observed for ecological site R028AY221 (basin big sagebrush) and R028AY226 (Wyoming big sagebrush) due to the limited number of units available for analysis and the absence of a clear pattern of clustering. Because SMUs can consist of up to four ecological sites, and the spatial location of individual ecological sites within SMUs are not known, we can only apply this technique to soil mapping units that are dominated by a single ecological site. If ecological sites within SMUs could be mapped, we assume that this technique could be applied to the relevant ecological sites in all SMUs.

\section{IMPLICATIONS}

We developed a methodological approach that can be used by range conservationists and others actively working in the development of ecological site descriptions and their corresponding state-and-transition models. If the ability to characterize benchmarks exists for other areas that have correlations of ecological site descriptions to soil mapping units, then this application can be replicated with relative ease. Changes in ordination space for ecological site units can then be evaluated and interpretations about their trajectories can be drawn. If benchmark data are correlated to MDS scores, then it will be possible to assess transitions and stable states. This type of activity can provide multitemporal quantitative support to existing STMs that have been developed using space-for-time substitutions of field observations.

A new area that is worth exploring by researchers is the prediction of the spatial distribution of ecological site descriptions on a pixel basis. Our results have suggested that a long-term remotely sensed data set provides sufficient information to discriminate sites with a major soil component. This is a relatively new application of remote sensing for rangelands. Our results provide evidence that ecological modeling of remotely sensed data sets has great potential for the future development of ecological sites and state-andtransition models. Spatiotemporal analysis of vegetation using remote sensing presents many possibilities for the future definition, interpretation, and display of ecological site information in rangelands (Brown 2010). The similarity index presented here can be used to generate triage maps to categorize the landscape into levels of similarity: a) high similarity to indicate that current conditions are close to the benchmark of undesired condition, b) moderate similarity to indicate areas that are moving toward undesired conditions, and c) low similarity to designate areas that are significantly different from undesired conditions. The condition in these areas (c) does not necessarily have to be good, however.

\section{ACKNOWLEDGMENTS}

This research was supported by the Utah Agricultural Experiment Station, Utah State University, and approved as journal paper number 8392. Funding was also obtained from the Intermountain Region Digital Image Archive Center (IRDIAC) project, which is sponsored by the National Aeronautics and Space Administration (NASA), and Utah State University. We also appreciate the help from two anonymous reviewers whose comments and observations greatly improved this paper.

\section{LITERATURE CITED}

Allen-Diaz, B., and J. W. Bartolome. 1998. Sagebrush-grass vegetation dynamics: comparing classical and state-transition models. Ecological Applications 8:795804.

Austin, M. P. 1977. Use of ordination and other multivariate descriptive methods to study succession. Vegetatio 35:165-175.

Benkobi, L., D. W. Uresk, and R. D. Child. 2007. Ecological classification and monitoring model for the Wyoming big sagebrush shrubsteppe habitat type of northeastern Wyoming. Western North American Naturalist 67:347-358.

Bestelmeyer, B. T., J. R. Brown, K. M. Havstad, R. Alexander, G. Chavez, and J. E. HeRRICK. 2003. Development and use of state-and-transition models for rangelands. Journal of Range Management 56:114-126.

Briske, D. D., S. D. Fuhlendor, and E. E. Smeins. 2005. State-and-transition models, thresholds, and rangeland health: a synthesis of ecological concepts and perspectives. Rangeland Ecology \& Management 58:1-10.

Brown, J. R. 2010. Ecological sites: their history, status, and future. Rangelands 32(6):5-8.

Chander, G., B. L. Markham, and D. L. Helder. 2009. Summary of current radiometric calibration coefficients for Landsat MSS, TM, ETM+, and E0-1 ALI sensors. Remote Sensing of Environment 113:893-903.

Chavez, P. S. 1996. Image-based atmospheric corrections revisited and improved. Photogrammetric Engineering and Remote Sensing 62:1025-1036. 
Cox, T. F. 2001. Multidimensional scaling used in multivariate statistical process control. Journal of Applied Statistics 28:365-378.

Crist, E. P., and R. J. Kauth. 1986. The tasseled cap de-mystified. Photogrammetric Engineering and Remote Sensing 52:81-86.

Foran, B. D., G. Bastin, AND K. A. Shaw. 1986. Range assessment and monitoring in arid lands-the use of classification and ordination in range survey. Journal of Environmental Management 22:67-84.

Huete, A. R. 1988. A soil-adjusted vegetation index (SAVI). Remote Sensing of Environment 25:295-309.

Hunt, E. R., J. H. Everitt, J. C. Ritchie, M. S. Moran, D. T. Booth, G. L. Anderson, P. E. CLARK, AND M. S. SeYFRIED. 2003. Applications and research using remote sensing for rangeland management. Photogrammetric Engineering and Remote Sensing 69:675-693.

Jensen, J. R. 2007. Remote sensing of the environment: an earth resource perspective. Upper Saddle River, NJ, USA: Pearson Prentice Hall. 592 p.

Kelly, A. M., and K. E. BAsford. 2000. Pattern analysis in grassland and animal production systems. In: L. t'Mannetje and R. M. Jones [EDs.]. Field and laboratory methods for grassland and animal production research. Wallingford, UK: CABI Publishing. p. 9-28.

Lattin, J. M., J. D. Carroll, and P. E. Green. 2003. Analyzing multivariate data. Pacific Grove, CA, USA: Thomson Brooks/Cole. 556 p.

Loerch, C., K. D. Adams, and V. Parslow. 1997. Soil survey of Box Elder County, Utah, western part. Washington, DC, USA: USDA. $223 \mathrm{p}$.

Lowry, J., R. D. Ramsey, K. Thomas, D. Schrupp, T. Sajwaj, J. Kirby, E. Waller, S. Schrader, S. Falzarano, L. Langs, G. Manis, C. Wallace, K. Schulz, P. Comer, K. Pohs, W. Rieth, C. Velasquez, B. Wolk, W. Kepner, K. Boykin, L. O'Brien, D. Bradford, B. Thompson, and J. Prior-Magee. 2007. Mapping moderate-scale landcover over very large geographic areas within a collaborative framework: a case study of the Southwest Regional Gap Analysis Project (SWReGAP). Remote Sensing of Environment 108:59-73.

Maynard, C. L., R. L. Lawrence, G. A. Nielsen, and G. Decker. 2007. Ecological site descriptions and remotely sensed imagery as a tool for rangeland evaluation. Canadian Journal of Remote Sensing 33:109-115.

PARKer, A. J. 1982. The topographic relative moisture index: an approach to soilmoisture assessment in mountain terrain. Physical Geography 3:160-168.

Pellant, M. 1996. Cheatgrass: the invader that won the West. Boise, ID, USA: USDIBLM Interior Columbia Basin Ecosystem Management Process. 22 p..

Pellant, M., P. Shaver, D. A. Pyke, and J. E. Herrick. 2005. Interpreting indicators of rangeland health, version 4. Denver, CO, USA: USDI-BLM National Science and Technology Center. Technical Reference 1734-6. 122 p.

PICKUP, G., AND B. D. Foran. 1987. The use of spectral and spatial variability to monitor cover change on inert landscapes. Remote Sensing of Environment 23:351-363.

PRISM Climate Group. 2004. PRISM Climate group web site. PRISM Climate Group, Oregon State University. Available at: http://www.prismclimate.org. Accessed 1 January 2009.

Pyke, D. A., J. E. Herrick, P. Shaver, and M. Pellant. 2002. Rangeland health attributes and indicators for qualitative assessment. Journal of Range Management 55:584-597.

R-Project. 2010. The R Project for Statistical Computing. Available at: http://www. r-project.org. Accessed 5 January 2007.
SANT, E. D. 2005. Identifying temporal trends in treated sagebrush communities using remotely sensed imagery [thesis]. Logan, UT, USA: Utah State University. $111 \mathrm{p}$.

StATSOFt. 2010. Multidimensional scaling. Available at: http://www.statsoft.com/ textbook/multidimensional-scaling/?button=2. Accessed 5 January 2010.

SWREGAP. 2004. Southwest regional gap analysis project: provisional digital land cover map for the Southwestern United States. Version 1.0. Available at: http:// earth.gis.usu.edu/swgap/. Accessed 5 January 2007.

[UDWR] Utah Division of WiLdLFE Resources. 2010. Utah big game range trend studies. Available at: http://wildlife.utah.gov/range/. Accessed 10 January 2007.

URESK, D. W. 1990. Using multivariate techniques to quantitatively estimate ecological stages in a mixed grass prairie. Journal of Range Management 43:282-285.

USDA-ARS. 2010. Jornada Experimental Range. Available at: http://usda-ars.nmsu. edu/esd/esdlntro.html. Accessed 10 January 2007.

USDA-NRCS. 2006a. Inventorying and monitoring grazing land resources. National range and pasture handbook. Available at: ftp://ftp-fc.sc.egov.usda.gov/GLTI/ technical/publications/nrph/nrph-ch4.pdf. Accessed 10 January 2008.

USDA-NRCS. 2006b. MLRA 28A—Great Salt Lake Area. Available at: http://www.ut. nrcs.usda.gov/technical/technology/range/mlra28a.html. Accessed 27 January 2011.

USDA-NRCS. 2008. National soil survey handbook. Available at: http://soils.usda. gov/technical/handbook/download.html. Accessed 1 May 2010.

USDA-NRCS. 2010a. Ecological site descriptions system. Available at: http://esis.sc. egov.usda.gov/Welcome/pgReportLocation.aspx?type=ESD. Accessed 12 January 2010.

USDA-NRCS. 2010b. Soil survey geographic SSURGO database NRCS soils. Available at: http://soils.usda.gov/survey/geography/ssurgo/. Accessed 10 January 2010.

USGS-EROS. 2010. Remote sensing phenology. Available at: http://phenology.cr. usgs.gov/get_data.php. Accessed 2 May 2008.

Washington-Allen, R. A., R. D. Ramsey, N. E. West, and B. E. Norton. 2008. Quantification of the ecological resilience of drylands using digital remote sensing. Ecology and Society 33(1):13. Available at: http://www.ecologyandsociety.org/ vol13/iss1/art33/.

Washington-Allen, R., N. E. West, R. D. Ramsey, and R. A. Efroymson. 2006. A protocol for retrospective remote sensing-based ecological monitoring of rangelands. Rangeland Ecology \& Management 59:19-29.

WEST, N. E. 1991. Benchmarks for rangeland management and environmental quality. In: L. F. James, J. O. Evans, M. H. Ralphs, and R. D. Child [EDs.]. Proceedings of the Noxious Range Weed Conference; 6-9 August 1991; Logan, UT, USA. Boulder, CO, USA: Westview Press. p. 30-44.

Westoby, M., B. Walker, and I. Noy-Meir. 1989. Opportunistic management for rangelands not at equilibrium. Journal of Range Management 42:266-274.

Wisdom, M., M. Rowland, L. Suring, L. Shueck, C. Meinke, and S. Knick. 2005a. Evaluating species of conservation concern at regional scales. In: M. Wisdom, M. Rowland, and L. Suring [EDS.]. Habitat threats in the sagebrush ecosystem: methods of regional assessment and applications in the Great Basin. Lawrence, KS, USA: Alliance Communications Group. p. 5-74.

Wisdom, M., M. RoWland, AND R. TAusCh. 2005b. Effective management strategies for sage-grouse and sagebrush: a question of triage? Transactions, North American Wildlife and Natural Resources Conference 70:206-227. 